\title{
EDUKASI RAMAH LINGKUNGAN : PERSPEKTIF GENDER DALAM AGRIBISNIS EKOLOGIS
}

\author{
RANI ANDRIANI BUDI KUSUMO ${ }^{1)}$, ANNE CHARINA ${ }^{\text {1) }}$, YAYAT SUKAYAT ${ }^{1)}$ \\ ${ }^{1)}$ Program Studi Agribisnis Fakultas Pertanian Universitas Padjajdjaran, \\ Jatinangor Sumedang 45363. \\ email : raniandriani081@gmail.com
}

\begin{abstract}
The purpose of this study were to: 1) analyze the role of gender differences in the response of consumers as well as eco-friendly behavior; 2) Develop a model of eco-friendly education to encourage changes in society behavior. This research was conducted by survey techniques. Respondents in this study were consumers who shop through the 'Small Market' which numbered 60 people. Descriptive analysis and test are used to answer the purposes of this study. The results showed a significant difference between men and women in collective values, affective response, conative response and eco friendly behavior.To construct eco friendly behavior requires the responsibilities of all parties., Governments, producers, consumers, educational institutions and the media have their respective roles to be able to raise awareness of eco friendly behavior.
\end{abstract}

Key Words: Education, eco-friendly, gender

\section{PENDAHULUAN}

Ekonomi hijau merupakan sistem perekonomian yang bertujuan untuk meningkatkan kesejahteraan manusia dan kesetaraan sosial, dengan memperhatikan kelestarian lingkungan. Ekonomi hijau juga dapat diartikan sebagai perekonomian yang berkelanjutan dengan menekan polusi lingkungan, penghematan sumberdaya alam dan berkeadilan sosial.

Salah satu indikator gelombang ekonomi dan industri hijau adalah gencarnya kampanye dan pengarusutamaan kegiatan ramah lingkungan (eco practices), yang meliputi lingkungan yang bersahabat (eco friendly), bisnis yang ramah lingkungan (eco-business), inovasi yang ramah lingkungan (eco innovation) dan sebagainya. Indikator lainnya adalah terbentuknya komunitaskomunitas ramah lingkungan pada generasi-generasi dalam ruang perkotaan dan pedesaan termasuk aksi-aksi nyatanya (Setiawan, 2012).

Kelompok Tani Cipta Mandiri merupakan salah satu kelompok tani yang berusaha meningkatkan kesadaran konsumen akan isu lingkungan dengan memasarkan produk sayuran organik yang 'disisipi' dengan edukasi kepada konsumen mengenai isu ramah lingkungan.

Edukasi konsumen merupakan suatu penerapan konsep pendidikan di dalam bidang berkonsumsi barang atau jasa. Konsep dasar edukasi adalah suatu proses belajar menuju ke perubahan perilaku yang lebih positif, dewasa, bertanggung jawab dan bijaksana. Proses edukasi yang dilakukan oleh Kelompok Tani Cipta Mandiri diharapkan akan memberikan perubahan pengetahuan, sikap dan perilaku konsumen yang lebih bertanggung jawab terhadap kelestarian lingkungan, yang akan diukur melalui analisis respon konsumen. 
Selain peran edukasi mengenai lingkungan hidup, perilaku konsumen dalam mengkonsumsi bahan pangan organik dan juga perilaku ramah lingkungan turut dipengaruhi oleh beberapa faktor, seperti karakteristik demografis konsumen (umur, pendidikan, gender, tingkat pendapatan) dan juga pengetahuan juga persepsi konsumen mengenai gaya hidup ramah lingkungan. Beberapa penelitian telah dilakukan untuk mengidentifikasi karakteristik konsumen yang berwawasan lingkungan. Penelitian-penelitian tersebut menganalisis variabel kepedulian terhadap lingkungan dan perilaku pembelian yang berwawasan lingkungan (Lingyee, 1997; Chan, 1999; Chan \& Lau, 2000; Fotopoulos \& Krystallis, 2002)

Salah satu karakteristik demografi yang menarik untuk diteliti terkait dengan isu lingkungan adalah perbedaan gender. Perbedaan gender akan menunjukkan karakteristik perbedaan peran, keterampilan dan sikap yang mengarah pada isu ekologikal. Hasil penelitian Junaedi (2008) menunjukkan bahwa konsumen yang lebih aktif untuk mencari produk pangan organic kebanyakan adalah kaum wanita yang telah memiliki anak. Golongan konsumen tersebut lebih memperhatikan kualitas produk dibandingkan dengan harga dalam membuat keputusan pembelian. Penelitian lain di Singapura yang dilakukan oleh Jiuan et al (2008) juga menunjukkan peran wanita dalam kehidupan mempengaruhi kesadaran mereka akan permasalahan lingkungan. Namun penelitian lain menunjukkan hasil yang berbeda, seperti dijelaskan oleh Ling-yee (1997) dalam penelitiannya di Hongkong, bahwa pria lebih peduli terhadap isu lingkungan. Dengan demikinan dapat diasumsikan bahwa lingkungan sosial budaya yang berbeda menentukan peran gender terhadap nilai-nilai ekologikal yang dapat mempengaruhi keputusan pembelian produk ramah lingkungan, termasuk pembelian bahan pangan organik. Ketidaksepakatan terhadap peraan gender dalam isu ekologikal menunjukkan bahwa perbedaan gender memiliki kemampuan memoderasi hubungan antar variabel penelitian model edukasi konsumen guna meningkatkan kesadaran masyarakat akan kelestarian lingkungan.

Engels (dalam Fakih, 1997) menjelaskan bahwa perbedaan gender antara laki-laki dan perempuan terjadi dalam proses yang panjang, dimulai dari proses sosialisasi, penguatan dan kontruksi sosial, kultural dan keagamaan bahkan melalui kekuasaan negara. Peran gender sebagai sebuah konseep merupakan hasil pemikiran manusia yang dibentuk oleh sistem sosial. Gender bersifat dinamis dan tidak bersifat universal karena perbedaan adat istiadat, budaya, agama dan sistem nilai dapat melahirkan perbedaan peran gender.

Dalam penelitian ini akan dianalisis respon konsumen terhadap edukasi ramah lingkungan, dengan melihat perspektif gender sebagai variabel pemoderasi sehingga akhirnya dapat dikembangkan sebuah model edukasi yang berkaitan dengan isu ramah lingkungan dengan menganalisis perbedaan peran gender di dalamnya. Model yang dihasilkan diharapkan dapat menjadi sumbangan pemikiran bagi para pemangku kepentingan (pemerintah, produsen dan pemasar produk pertanian serta konsumen), mengenai upaya peningkatan kesadaran bersama akan permasalahan lingkungan, terutama yang terkait dengan isu kesehatan dan degradasi lingkungan hidup.

Berdasarkan pemaparan di atas, tujuan dari penelitian ini adalah untuk :

1. Menganalisis perbedaan peran gender pada respon konsumen serta perilaku ramah lingkungan 
2. Menyusun model edukasi ramah lingkungan untuk mendorong perubahan perilaku masyarakat yang ramah lingkungan.

\section{METODE PENELITIAN}

Penelitian ini merupakan bagian dari penelitian yang berjudul "Model Edukasi Ramah Lingkungan : Perspektif Gender dalam Agribisnis Ekologis". Penelitian ini merupakan penelitian kuantitatif dengan teknik survey. Penelitian dilakukan di Kelompok Tani Cipta Mandiri Kabupaten Bandung. Pemilihan lokasi penelitian dilakukan secara sengaja dengan pertimbangan : 1) Kelompok tani Cipta Mandiri merupakan produsen sayuran organic; 2) Kelompok tani Cipta Mandiri melakukan edukasi kepada konsumen.

Populasi dari penelitian ini adalah konsumen yang membeli produk sayuran organic produksi kelompok tani Cipta Mandiri melalui 'Pasar Kecil'. Saat ini Kelompok Tani Cipta Mandiri baru dapat melayani 60 orang konsumen yang berlangganan produk sayuran organik sebanyak 2 kali dalam 1 minggu. Seluruh konsumen tersebut akan dijadikan responden dalam penelitian ini melalui metoda sensus.

Adapun variabel yang dianalisis dalam penelitian ini adalah :

1. Karakteristik demografis konsumen sayuran organik. Sub variabel yang akan dianalisis adalah umur, gender, tingkat pendidikan, tingkat pendapatan, status pernikahan, penggunaan media sebagai sumber informasi mengenai isu ramah lingkungan.

2. Nilai - nilai ekologis

Nilai - nilai ekologis yang berpengaruh pada perilaku konsumen dianalisis berdasarkan nilai individual dan kolektif

a. Nilai orientasi individual tediri dari tiga dimensi yaitu "keinginan mencapai tujuan, pengarahan diri, dan pemenuhan diri.

b. Nilai kolektif menunjukkan konsumen lebh mempertimbangkan tujuan kelompok dibandingkan tujuan individual.

3. Respon konsumen terhadap edukasi ramah lingkungan yang dilakukan oleh Kelompok Tani Cipta Mandiri diukur melalui 3 dimensi, yaitu respon kognitif, afektif dan konatif.

a. Dimensi kognitif (pengetahuan) berisi persepsi, opini, kesadaran konsumen terhadap edukasi ramah lingkungan yang dapat dilihat melalui pemahaman terhadap tujuan, keunggulan dan manfaat edukasi ramah lingkungan.

b. Dimensi afektif (sikap) merupakan perasaan konsumen dan terkait masalah emosi terhadap tujuan, keunggulan dan manfaat edukasi ramah lingkungan.

c. Dimensi konatif yaitu kecenderungan untuk bertindak atau bereaksi terhadap program edukasi ramah lingkungan yang ditunjukkan dengan keinginan untuk melakukan pembelian produk sayuran organik dan keinginan untuk berkomitmen terhadap aktivitas yang mendukung kelestarian lingkungan.

Pengukuran variabel respon diukur melalui 5 poin skala Likert dari Sangat Tidak Setuju (STS) sampai Sangat Setuju (SS). 
4. Perilaku ramah lingkungan merupakan perilaku konsumen dalam membeli dan mengkonsumsi pangan organik dan juga perilaku ramah lingkungan dalam kehidupan sehari-hari

Pengukuran variabel perilaku ramah lingkungan diukur melalui 5 poin skala Likert dari Sangat Tidak Setuju (STS) sampai Sangat Setuju (SS).

Uji validitas dan reabilitas terhadap instrument penelitian mengenai respon dan perilaku ramah lingkungan yang terditi dari duabelas indikator memiiki koefisien korelasi masing-masing item dengan total (corr item total) lebih besar dari 0,30 . Untuk variabel respon dengan dimensi kognitif yang terdiri dari tiga indikator memiiki nilai alphacronbach sebesar 0,716; dimensi afektif yang terdiri dari tiga indikator memiliki nilai alpha cronbach sebesar 0,687; dimensi konatif yang terdiri dari tiga indikator memiliki nilai alpha cronbach sebesar 0,759 dan variabel perilaku ramah lingkungan yang terdiri dari tiga indikator memiliki nilai alpha cronbach sebesar 0,873 sehingga dapat dikatakan instrument penelitian valid dan reliable.

Data dikumpulkan melalui wawancara, observasi partisipatif dan FGD (Focus Group Discussion). Selanjutnya data dianalisis dengan metode deskriptif dan metode inferensia. Analisis deskriptif dilakukan dengan cara menggambarkan secara rinci data yang diperoleh dengan membuat tabulasi hasil jawaban responden lalu dipresentasikan. Analisis deskriptif dalam penelitian ini digunakan untuk menganalisis karateristik responden dan menganalisis respon terhadap edukasi ramah lingkungan serta menganalisis perilaku ramah lingkungan. Untuk menganalisis perbedaan peran gender dalam respon konsumen serta perilaku ramah lingkungan, digunakan analisis uji beda t.

\section{HASIL DAN PEMBAHASAN \\ Karakteristik Konsumen}

Karakteristik konsumen berdasarkan jenis kelamin. Konsumen 'Pasar Kecil' sebagian besar adalah wanita (85\%). Secara tradisional wanita lebih berperan dalam pengambilan keputusan yang berhubungan dengan pembelian bahan makanan. Pada umumnya perempuan lebih berperan dalam pengambilan keputusan yang berhubungan dengan pembelian bahan makanan. Meskipun peran perempuan saat ini telah banyak bergeser, namun dalam sebagian besar keluarga di Indonesia, tanggung jawab dalam hal penyediaan makanan untuk keluarga tetap berada di tangan perempuan. Hal ini sejalan dengan penelitian Levy dan Lee (2010) yang menunjukkan perempuan biasanya menjadi pelopor dalam pengambilan keputusan, terutama yang berhubungan dengan peran perempuan sebagai ibu rumah tangga.

Karakteristik konsumen berdasarkan kelompok umur. Berdasarkan kelompok umur secara psikologis, konsumen pasar kecil didominasi oleh kelompok umur dewasa awal (26-35 tahun), yaitu sebanyak 60\%. Hasil penelitian Delita (2008) membahas bahwa konsumen sayuran segar didominasi oleh kelompok umur dewasa akhir dan lansia awal. Pengambil keputusan dan pelaku pembelian sayuran memang sebagian besar adalah mereka yang termasuk kelompok umur dewasa, meskipun mereka yang mengkonsumsi sayuran mencakup semua kelompok umur mulai dari anak-anak sampai dengan golongan lansia. Konsumen yang termasuk kelompok umur dewasa telah memiliki pemikiran yang rasional dalam mengambil keputusan pembelian. Konsumen 
golongan ini biasanya telah memahami atribut-atributproduk sayuran organik yang pada akhirnya menentukan perilaku pembelian.

Karakteristik konsumen berdasarkan status penikahan dan jenis pekerjaan. Konsumen yang berlangganan sayur di 'Pasar Kecil' sebagian besar sudah menikah (90\%). dan lebih dari separuh konsumen (60\%) berprofesi sebagai ibu rumah tangga. Ibu rumah tangga memiliki waktu yang cukup luang untuk berbelanja kebutuhan sehari-hari bagi keluarga nya, namun bagi perempuan yang bekerja sekalipun, tugas memenuhi kebutuhan konsumsi bagi keluarga sebagian besar tetap dijalankan oleh kaum wanita. Beberapa hasil penelitian juga menunjukkan konsumen sayuran sebagian besar adalah ibu rumah tangga (Delita, 2008), (Bertarjani, 2013). Hal ini berkaitan dengan peran tradisional wanita sebagai seseorang yang bertanggung jawab untuk mengurus kebutuhan keluarganya.

Karakteristik konsumen berdasarkan tingkat pendidikan. Dilihat dari tingkat pendidikan terakhir yang ditempuh, dapat dikatakan konsumen 'Pasar Kecil' memiliki latar belakang pendidikan yang cukup baik. Seluruh konsumen setidaknya menempuh pendidikan minimal tingkat SMA. Separuh konsumen berlatar pendidikan sarjana $(53,33 \%)$, bahkan ada beberapa konsumen yang menempuh pendidikan hingga tingkat pasca sarjana. Latar belakang pendidikan yang baik, menunjukkan konsumen memiliki tingkat pengetahuan dan tingkat kesadaran yang baik mengenai apa yang layak dikonsumsi oleh mereka atau keluarga nya. Selain itu, dengan latar pendidikan yang baik pula konsumen akan lebih aktif mencari informasi mengenai makanan yang sehat. Tingkat pendidikan akan mempengaruhi seseorang dalam menerima pengetahuan dan informasi. Seseorang yang memiliki tingkat pendidikan yang baik biasanya akan lebih memiliki sikap reponsif terhadap informasi, yang akhirnya akan mempengaruhi keputusan untuk mengkonsumsi sebuah produk (Sumarwan, 2003).

Karakteristik konsumen berdasarkan tingkat pendapatan. Pada penelitian ini yang dianalisis adalah besarnya pendapatan keluarga, yang artinya total seluruh pendapatan anggota keluarga. Besarnya pendapatan dapat menggambarkan besarnya daya beli seorang konsumen. Pendapatan merupakan sumberdaya material yang membiayai seseorang dalam kegiatan konsumsinya (Sumarwan, 2003). Sebagian besar konsumen $(74,99 \%)$ memiliki pendapatan di atas Rp. 6 juta per bulan. Golongan tersebut dapat dikatakan memiliki tingkat pendapatan yang cukup tinggi dan memiliki daya beli yang baik untuk mengkonsumsi sayuran organik.

\section{Nilai - Nilai Ekologis Konsumen}

Nilai ekologis merupakan nilai yang diyakini konsumen saat konsumen mengkonsumsi sayuran organik. Nilai ekologis yang mempengaruhi perilaku konsumen dianalisis berdasarkan nilai individual dan kolektif.

Nilai individual terdiri dari tiga dimensi yaitu keinginan mencapai tujuan, pengarahan diri serta pemenuhan diri. Sebagian besar konsumen telah menyadari akan manfaat sayuran organic sebelum mereka memutuskan untuk mengkonsumsi sayuran organic. Karakteristik konsumen sayuran organic yang memiliki tingkat pendididkan baik dan juga pendapatan yang cukup tinggi membuat konsumen lebih mempertimbangkan manfaatnya bagi kesehatan dan juga lingkungan hidup, meskpipun harga sayuran organic lebih mahal dibandingkan dengan sayuran konvensional. 
Sebelum memutuskan untuk mengkonsumsi sayuran organic, konsumen mencari informasi mengenai apa itu sayuran organic, manfaat dan bagaimana memperolehnya. Setelah mereka percaya akan manfaat akan sayuran organic, konsumen terdorong untuk mengkonsumsinya. Sebagian besar konsumen mengkonsumsi sayuran organic berdasarkan kesadaran dari diri mereka sendiri. Hanya sebagian kecil konsumen yang mengaku mengkonsumsi sayuran organic karena dorongan dari luar dirinya sendiri, seperti karena dipengaruhi oleh faktor lingkungan dan juga gaya hidup masyarakat modern.

Nilai kolektifmenggambarkan konsumen lebih mempertimbangkan tujuan kelompok daripada tujuan individual. Dalam budaya kolektivis, perilaku diatur terutama oleh norma-norma dalam kelompok yangmerupakan penentu penting dari perilaku sosial. Kolektivisme mencerminkan konsumen yang lebih mempertimbangkan tujuan kelompok daripada tujuan individual (Konsky et al, 2000). Dalam penelitian ini, nilai orientasi kolektif menggambarkan pengaruh faktor lingkungan terhadap keputusan pembelian sayuran organik.

Sebagian besar konsumen menyatakan bahwa mereka membeli sayuran organic karena pengaruh dari orang lain di lingkungan nya. Kelompok Tani Cipta Mandiri membuat sistem pemasaran yang dapat diakses melalui media sosial, sehingga media sosial itu sendiri berperan dalam menyebarkan informasi dan mendorong konsumen melalukan pembelian setelah mereka melihat akun milik kelompok tani Cipta Mandiri. Selain faktor tersebut, faktor lingkungan lain sepert gaya hidup masyarakat yang sudah mengarah pada konsumsi produk organic, faktor keluarga, informasi akan kesehatan juga menjadi pendorong konsumen untuk melalukan pembelian sayuran organic. Menurut Engel et al (1994) terdapat tiga faktor utama yang berpengaruh terhadap keputusan pembelian, yaitu faktor budaya, kelas sosial serta pengaruh keluarga dan lingkungan.

Gaya hidup ramah lingkungan menggambarkan perilaku keseharian konsumen terhadap isu ramah lingkungan. Sebagian besar konsumen mengatakan sudah berperilaku ramah lingkungan, baik dalam hal konsumsi makanan organik, pemakaian produk ramah lingkungan, penerapan prinsip $3 \mathrm{R}$ (reduce, reuse dan recycle). Faktor lingkungan eksternal menjadi pendorong sebagian besar konsumen untuk mengikuti gaya hidup ramah lingkungan. Konsumen mengikuti gaya hidup ramah lingkungan karena terlebih dahulu melihat orang di sekitarnya melalukan hal serupa. Amstrong dalam Nugraheni (2003) menjelaskan bahwa gaya hidup dapat dipengaruhi oleh faktor eksternal, seperti keluarga, kelompok referensi, budaya ataupun kelas sosial. Interaksi dengan orang lain dalam kelompok sosial dapat menularkan kebiasaan atau perilaku, yang akhirnya membentuk perilaku individu yang ramah lingkungan.

\section{Respon Konsumen Terhadap Edukasi Ramah Lingkungan}

Respon konsumen terhadap edukasi ramah lingkungan yang dilakukan oleh Kelompok Tani Cipta Mandiri diukur melalui 3 dimensi, yaitu dimensi kognitif, afektif dan konatif. Respon kognitif berisi persepsi, opini, kesadaran konsumen terhadap edukasi ramah lingkungan yang dapat dilihat melalui pemahaman terhadap tujuan, keunggulan dan manfaat edukasi ramah lingkungan. Dari hasil wawancara, diketahui bahwa sebagian besar konsumen mengetahui isi pesan akan gaya hidup ramah lingkungan dan lebih dari separuh konsumen memahami secara jelas tujuan dari isi pesan tersebut (65\%). Sebagian besar konsumen mengatakan bahwa ketika melihat isi pesan tersebut di media sosial, 
mereka memahami ajakan untuk hidup sehat dan peduli terhadap lingkungan. Namun sebagian konsumen menilai isi pesan tersebut sama saja dengan pesan ramah lingkungan lainnya dan kurang memahami secara spesifik maksud di balik pesan tersebut.

Lebih dari separuh konsumen $(63,33 \%)$ memahami keunggulan edukasi ramah lingkungan yang disampaikan melalui pasar kecil. Konsumen merasa tertarik dengan konsep pemasaran melalui pasar kecil, dimana konsumen mendapatan 'paket ramah lingkungan', mulai dari sayuran organi, resep masakan seat, hingga kemasan sayur yang juga ramah lingkungan. Melalui cara tersebut, konsumen merasa mendapatkan manfaat lebih, yaitu 'edukasi' mengenai gaya hidup sehat. Melalui konsep yang dibuat dalam pasar kecil, konsumen juga merasa didorong dan dibiasakan melakukan gerakan ramah lingkungan, contohnya dalam penggunaan keranjang dan tas belanja yang reusable. Sebagian besar konsumen $(80 \%)$ juga memahami manfaat dari edukasi tersebut untuk merubah dan mendorong kebiasaan konsumen untuk lebih peduli terhadap lingkungan.

Respon afektif merupakan perasaan konsumen dan terkait masalah emosi terhadap tujuan, keunggulan dan manfaat edukasi ramah lingkungan. Sebagian besar konsumen merasa tertarik akan tujuan, manfaat dan metode edukasi ramah lingkungan yang dilakukan oleh kelompok tani Cipta Mandiri . Dalam wawancara terungkap sebagian besar konsumen sudah mengkonsumsi produk organic sebelum mereka menjadi konsumen pasar kecil, karena mereka menyadari pentingnya menjaga kesehatan. Namun konsumen mengakui mereka tertarik akan hal yang disampaikan dalam pasar kecil, sehingga akhirnya mereka berlangganan produk melalui pasar kecil. Menurut konsumen, edukasi yang disampaikan melalui pasar kecil cukup efektif untuk menyadarkan dan mendorong konsumen untuk hidup lebih sehat dan peduli terhadap lingkungan.

Respon konatif merupakan kencenderungan untuk bertindak atau bereaksi terhadap program edukasi ramah lingkungan yang ditunjukkan dengan keinginan untuk melakukan pembelian produk sayuran organik dan keinginan untuk berkomitmen pada aktivitas yang mendukung kelestarian lingkungan. Berdasarkan hasil wawancara diketahui bahwa sebagian besar konsumen $(98,34 \%)$ berkeinginan untuk selalu mengkonsumsi produk pangan organic. Sebagian besar konsumen (70\%) juga berkeinginan untuk selalu berperilaku ramah lingkungan dan juga berkeinginan dapat mengajak orang lain untuk juga peduli terhadap lingkungan. Konsumen berharap semakin banyak masyarakat yang menyadari pentingnya menjaga kelestarian lingkungan. Hal tersebut sejalan dengan hasil penelitian Susilo (2014) yang menunjukkan bahwa konsumen yang memiliki kesadaran tinggi akan isu lingkungan akan semakin menyadari hubungan antara gaya hidup dan cara konsumsi individu terhadap masalahmasalah sosial dan lingkungan dalam skala yang lebih luas, baik pada tingkat nasional maupun global.

\section{Perilaku Ramah Lingkungan}

Perilaku ramah lingkungan yang ditunjukkan oleh sebagian besar konsumen diantaranya adalah selalu menjaga kelestarian lingkungan $(86,66 \%)$, serta selalu mengkonsumsi pangan organik sebagai bagian dari usaha menjaga kelestarian lingkungan (91,66\%). Sebagian besar konsumen $(93,27 \%)$ juga bersedia membayar lebih untuk produk ramah lingkungan, karena mereka 
menyadari 'nilai tambah' dari mengkonsumsi produk yang ramah lingkungan, baik untuk diri sendiri maupun sebagai kontribusi untuk menjaga kelestarian lingkungan.

\section{Analisis Gender Terhadap Respon dan Perilaku Ramah Lingkungan}

Untuk melihat perbedaan peran gender dalam respon dan perilaku ramah lingkungan, dilakukan dengan uji beda rata-rata kelompok konsumen pria dan wanita dalam setiap variabel penelitian secara parsial. Analisis ini dilakukan untuk memberikan gambaran perbedaan persepsi antara pria dan wanita dalam variabel nilai individu, nilai kolektf, respon kognitif, respon konatif serta perilaku ramah lingkungan. Secara rinci perbedaan peran gender terhadap berbagai variabel dapat dilihat pada Tabel 1 berikut.

Tabel 1. Hasil Uji Beda Peran Gender dalam Variabel Penelitian

\begin{tabular}{lccccc}
\hline \multicolumn{1}{c}{ Variabel } & Gender $^{*}$ & n & Mean & Uji t & Signifikansi \\
\hline Orientasi Individu & 1 & 11 & 12.76 & 2.502 & .329 \\
Orientasi Kolektif & 2 & 49 & 12.90 & & \\
& 1 & 11 & 6.82 & 3.702 & $.002^{*}$ \\
Respon Kognitif & 2 & 49 & 8.51 & & \\
& 1 & 11 & 12.27 & 0.256 & .801 \\
Respon Afektif & 1 & 49 & 12.18 & & \\
Respon Konatif & 2 & 11 & 6.55 & & $.000^{*}$ \\
Perilaku Ramah & 1 & 49 & 12.27 & & \\
Lingkungan & 2 & 49 & 12.69 & 27.796 & $.000^{*}$ \\
\hline
\end{tabular}

Keterangan : Gender (1) : Pria; (2) : Wanita

Hasil uji beda antara kelompok konsumen pria dan wanita menunjukkan terdapat perbedaan yang signifikan $(\mathrm{p}<0,05)$ antara pria dan wanita dalam nilai kolektif, respon afektif, respon konatif dan perilaku ramah lingkungan. Tidak terdapat perbedaan antara pria dan wanita dalam hal pengetahuan mengenai edukasi ramah lingkungan $(p>0,05)$. Sama halnya dengan pembahasan sebelumnya bahwa karakteristik demografis lain seperti umur, tingkat pendidikan dan pendapatan tidak menunjukkan perbedaan pengaruh dalam hal pengetahuan konsumen terhadap edukasi ramah lingkungan. Baik pria maupun wanita memiliki tingkat pengetahuan yang cukup baik dalam edukasi ramah lingkungan. Hal ini menunjukkan bahwa baik pria dan wanita memiliki kesadaran yang baik untuk mengikuti gaya hidup ramah lingkungan, dan mereka mengetahui bahwa ketika membeli sayuran dari 'Pasar Kecil', secara tidak langsung konsumen mendapatkan edukasi mengenai gaya hidup ramah lingkungan dengan membiasakan diri menggunakan reusable bag ketika berbelanja dan juga mengikuti resep sehat yang diberikan dalam paket sayuran.

Tidak terdapat perbedaan yang signifikan antara nilai individu konsumen pria dan wanita. Hal ini menunjukkan baik pria dan wanita menjalani gaya hidup sehat dan ramah lingkungan karena memiliki keyakinan yang kuat akan manfaat gaya hidup sehat dan ramah lingkungan. Namun dalam nilai kolektif dapat dilihat 
bahwa wanita lebih memiliki nilai kolektif dalam menjalankan gaya hidup ramah lingkungan, yang artinya wanita lebih dipengaruhi faktor di luar dirinya, termasuk faktor keluarga dalam mengambil keputusan untuk menjalankan gaya hidup yang ramah lingkungan. Jika dikaitkan dengan konsumsi pangan organic, dapat dijelaskan bahwa wanita memiliki peran dan tanggung jawab yang lebih besar dalam menyediakan bahan pangan bagi keluarga nya, oleh karena itu dalam memilih jenis sayuran yang akan dikonsumsi wanita akan mempertimbangkan beragam faktor, seperti kesehatan anggota keluarga dan juga kondisi keuangan keluarga. Menurut Straughan dan Robert dalam Junaedi (2008) disebutkan bahwa wanita dalam menjalankan perannya lebih mempertimbangkan pengaruh dari keputusan yang diambil terhadap orang lain. Penelitian Ling Yee (1997) juga menjelaskan bahwa gender, status menikah dan jumlah anak turut memoderasi nilai, sikap dan perilaku konsumen dalam berkomitmen untuk melestarikan lingkungan. Hal ini menunjukkan bahwa bagi para wanita faktor keluarga ikut menjadi penentu bagi wanita dalam menjalankan gaya hidup ramah lingkungan. Selain itu wanita juga lebih dipengaruhi oleh informasi dari lingkungan sekitarnya atau komunitasnya dalam memilih sebuah produk tertentu

Pada variabel respon afektif dan respon konatif, terdapat perbedaan yang nyata antara pria dan wanita $(\mathrm{p}<0,05)$. Hal ini menunjukkan bahwa wanita lebih tertarik pada kegiatan edukasi ramah lingkungan dan ingin selalu menerapkan gaya hidup ramah lingkungan dan ingin menularkan hal tersebut kepada orang lain. Beberapa hasil penelitian menunjukkan bahwa wanita lebih selektif dan teliti dalam memilih produk makanan dibandingkan konsumen pria. Penelitian Benner dan Derby dalam Junaedi (2008) menunjukkan wanita lebih teliti dalam membaca label kandungan nutrisi dalam kemasan makanan. Kembali ketika dikaitkan dengan peran wanita, sikap wanita ini memang terkait dengan tanggung jawab wanita untuk menyediakan pangan yang sehat bagi keluarga. Secara tidak langsung ketika seorang konsumen wanita telah memilih untuk menjalankan gaya hidup sehat dan ramah lingkungan, pola hidup tersebut akan menjadi suatu bentuk pembiasaan dan edukasi bagi anggota keluarga lainnya untuk ikut menjalankannya. Oleh karena itu wanita berperan penting dalam mengedukasi anggota keluarga lainnya terutama pada anaknya.

Uji beda pada variabel perilaku ramah lingkungan menunjukkan perbedaan yang signifikan antara konsumen pria dan wanita (Tabel 3), dimana wanita lebih berkomitmen untuk selalu berperilaku ramah lingkungan dan bersedia membayar lebih untuk produk ramah lingkungan dibandingkan konsumen pria. Penelitian Junaedi (2008) menunjukkan hal yang sebaliknya, dimana pria bersedia membayar dengan harga premium dibandingkan wanita.

\section{Model Edukasi Ramah Lingkungan untuk Mendorong Perubahan Perilaku Masyarakat yang Ramah Lingkungan}

Kesadaran masyarakat akan isu lingkungan hidup sudah mulai tumbuh. Namun berbagai hasil kajian menunjukan bahwa pengetahuan, kesadaran dan minat sebagian masyarakat Indonesia dalam berperilaku ramah lingkungan masih tergolong rendah (Junaedi, 2008; Susilo, 2014). Yuniarto (2013) menambahkan bahwa rendahnya kesadaran masyarakat terhadap kelestarian lingkungan meliputi hamper semua kalangan, baik rumah tangga, perusahaan hingga kebijakan yang kurang mendukung kelestarian lingkungan. 
Namun perkembangan isu lingkungan hidup dalam dunia pemasaran global telah berkembang. Konsumen di negara maju menuntut perusahaan menjalankan bisnis secara hijau dan mendorong tumbuhnya tanggung jawab sosial perusahaan (Susilo, 2014). Perkembangan tersebut mulai dipenetrasikan oleh perusahaan multinasional dalam memasarkan produk atau jasa pada konsumen Indonesia. Perusahaan memiliki tangggung jawab untuk melahirkan konsumen yang berperilaku hijau (Susilo, 2014)

Kegiatan pemasaran yang dilakukan oleh kelompok tani Cipta Mandiri melalui 'Pasar Kecil' dapat dikatakan telah mengarah pada kegiatan bisnis yang ramah lingkungan. Meskipun dengan skala usaha yang belum terlalu besar, kelompok tani Cipta Mandiri dengan didampingi oleh organisasi nirlaba 'Hivos' mampu memasarkan produk sayuran organic dengan konsep relationship marketing dan secara tidak langsung juga mengedukasi konsumen nya. Konsep pemasaran tersebut terbukti mampu menarik konsumen untuk membeli produk ramah lingkungan, yang ditunjukkan dengan perkembangan jumlah pembeli. Hasil kajian ini menunjukkan kegiatan edukasi yang dilakukan melalui 'Pasar Kecil' juga mendapatkan respon yang cukup positif dari konsumen. Dimulai dengan edukasi penggunaan kemasan produk yang ramah lingkungan dan saran pengolahan sayuran yang sehat, langkah tersebut diharapkan mampu membentuk perilaku konsumen untuk lebih sadar lingkungan dan juga kesehatan. Hal ini menunjukkan bahwa bentuk edukasi ramah lingkungan tidak melulu hanya tanggung jawab perusahaan besar. Melalui komunitas - komunitas yang ada di masyarakat, edukasi dapat dilakukan dengan bentuk yang kreatif. Berdasarkan pengalaman tersebut, maka konsep yang dilakukan oleh kelompok tani Cipta Mandiri dapat dikembangkan untuk membangun kesadaran masyarakat, mengenai isu ramah lingkungan.

Dalam meningkatkan kesadaran masyarakat akan lingkungan, perlu keterlibatan semua pihak untuk mendukung kegiatan ini. Tanggung jawab terhadap lingkungan bukan lah kewajiban sebagian pihak saja. Namun tenntunya diperlukan strategi pengembangan yang berbeda-beda tergantung peran seseorang di dalam masyarakat.

Petani sebagai produsen memiliki peran yang penting dalam mendorong kesadaran masyarakat akan isu ramah lingkungan. Melalui konsep dan strategi pemasaran yang menarik, produsen dapat menarik konsumen untuk membeli produk ramah lingkungan. Engel et al (1994) mengatakan pengetahuan konsumen merupakan faktor penentu utama konsumen dalam berperilaku. Penelitian Susilo (2014) menunjukkan pengetahuan konsumen perpengaruh terhadap perilaku hijau konsumen dalam mengkonsumsi minuman yang dibelinya. Saat seorang konsumen telah teredukasi untuk mengkonsumsi produk secara hijau dan memiliki pengetahuan yang cukup maka pengetahuan tersebut secara langsung dapat mempengaruhi konsumen dalam melakukan konsumsi yang hijau pula.

Konsumen sebagai pihak yang memiliki kekuatan untuk menentukan apa yang dikonsumsinya memiliki peran untuk terus berkomitmen terhadap isu lingkungan dan juga dapat mempengaruhi orang lain dalam lingkungannya untuk ikut berperilaku ramah lingkungan. Dalam penelitian ini, didapatkan kesimpulan bahwa peran gender yang berbeda menggambarkan sikap, niat dan perilaku yang berbeda antara pria dan wanita. Model yang dikembangkan akan lebih menyoroti 
peran wanita sebagai ibu rumah tangga dalam mengedukasi anggota keluarga lainnya.

Upaya untuk mendorong kesadaran perilaku ramah lingkungan dalam lingkungan keluarga dapat dianaliais melalui faktor ekologis yang mempengaruhi kepribadian dan nilai yang dianut oleh seorang individu, seperti apa yang dijelaskan oleh teori Brofenbrenner (1981) dan juga dijabarkan oleh Berns (1997) yang menggambarkan bagaimana sosialisasi dan dukungan bagi perkembangan anak dengan menggambarkan interaksi sistem mikro, meso, ekso, dan makro.

Keluarga sebagai lingkungan terdekat (sistem mikro) bagi seorang individu adalah faktor lingkungan yang diharapkan memberikan peran yang cukup besar dalam mendorong kesadaran akan isu lingkungan. Keluarga merupakan unit sosial terkecil dalam masyarakat merupakan tempat sosialisasi pertama untuk mengajarkan berbagai nilai dan norma dalam masyarakat, dan dapat dikatakan segala sesuatu dimulai dalam kehidupan keluarga. Berdasarkan perannya, wanita berperan untuk mengkampanyekan kesadaran lingkungan pada anggota keluarganya. Anak - anak yang dididik dan terbiasa denga pola hidup sehat dan ramah lingkungan yang dilakukan orang tua, terutama ibunya akan lebih berpeluang untuk secara konsisten berperilaku ramah lingkungan.

Lembaga pendidikan sebagai lingkungan terdekat bagi seorang anak, setelah keluarga,dengan dukungan kebijakan dari instansi terkait dapat mendorong siswanya untuk berperilaku ramah lingkungan dengan memasukkan muatan lingkungan hidup dalam berbagai mata pelajaran di sekolah. Pihak sekolah juga dapat membentuk karakter siswa nya dalam berperilaku hijau melalui berbagai peraturan dan juga kegiatan di sekolah.

Media mempunyai tanggung jawab untuk memberikan informasi kepada masyarakat untuk lebih peduli dan aktif terhadap kelestarian lingkungan. Selain itu media juga berperan dalam advokasi lingkungan. Sekretariat Green Economy Caucus ${ }^{2}$ pada 26 Desember - 31 Desember 2014, telah melakukan penelusuran media mengenai berita tentang lingkungan. Tujuan daripada penelusuran tersebut adalah melakukan analisa terhadap sejauh mana media memberikan perhatian terhadap isu-isu dan persoalan lingkungan, dengan fokus survei adalah media online nasional yang jangkauan / aksesibilitasnya cukup luas di publik baik berupa pemasaran produknya, maupun company branding-nya. Hasil kajian tersebut menunjukkan bahwa pemberitaan masalah ekologis dari pemantauan selama satu minggu masih belum menjadi kebutuhan pengetahuan masyarakat. Kajian tersebut merekomendasikan agar pemerintah, parlemen, akademisi, maupun komunitas yang terkait untuk terus melakukan dorongan program dan juga meningkatkan komitmen lembaga agar isu ekologis menjadi isu strategis sebagai basis informasi dan pengetahuan masyarakat ${ }^{3}$. Hal ini menunjukkan bahwa peran media sangat penting dalam menyediakan informasi bagi masyarakat terkait isu lingkungan. Selain itu, penggunaan media sosial yang semakin berkembang diharapkan mampu membangun hubungan jaringan sentiment diantara anggota nya agar dapat membangun kepedulian terhadap isu ramah lingkungan.

Dalam tataran makro, Pemerintah memiliki tanggung jawab dalam membangun kesadaran masyarakat untuk berperilaku ramah lingkungan. Melalui kewenangan untuk mengeluarkan kebijakan dan berbagai macam regulasi, pemerintah berwenang untuk mengendalikan segala hal yang berkaitan dengan isu 
lingkungan. Selain itu peran lembaga legislatif juga dibutuhkan untuk membuat green policy, karena pada akhirnya isu lingkungan berkaitan dengan arah kebijakan pemerintah... Melalui produk kebijakan, pemerintah misalnya dapat 'memaksa' produsen untuk menjadi produsen hijau dan mewajibkan perusahaan mengedukasi masyarakat melalui kegiatan tanggung jawab sosial perusahaan. Selain itu pemerintah juga dapat mengeluarkan aturan bagi konsumen untuk berperilaku ramah lingkungan, misalnya dengan mendorong konsumen untuk menggunakan reusable bag ketika berbelanja. Pemerintah juga dapat membuat aturan bagi media massa untuk menayangkan kampanye ramah lingkungan.

Membangun perilaku ramah lingkungan pada intinya memerlukan tanggung jawab semua pihak. Pihak lain yang berperan dalam meningkatkan kesadaran akan isu ramah lingkungan diantaranya adalah perguruan tinggi dan juga organisasi nirlaba. Kedua aktor ini dapat berperan membantu dan mendampingi produsen, dalam kasus ini adalah petani untuk menjalankan usaha yang mengarah pada pertanian yang ramah lingkungan, dan juga membantu produsen menciptakan pasar bagi produk ramah lingkungan. Perguruan tinggi dan organisasi nirlaba juga dapat mendorong produsen untuk ikut mengedukasi konsumennya dengan kegiatan-kegiatan kecil yang dapat mengajak konsumen untuk ikut berperilaku ramah lingkungan. Pada Gambar 1 dapat dilihat hubungan peran antar berbagai aktor untuk membangun perilaku ramah lingkungan. 


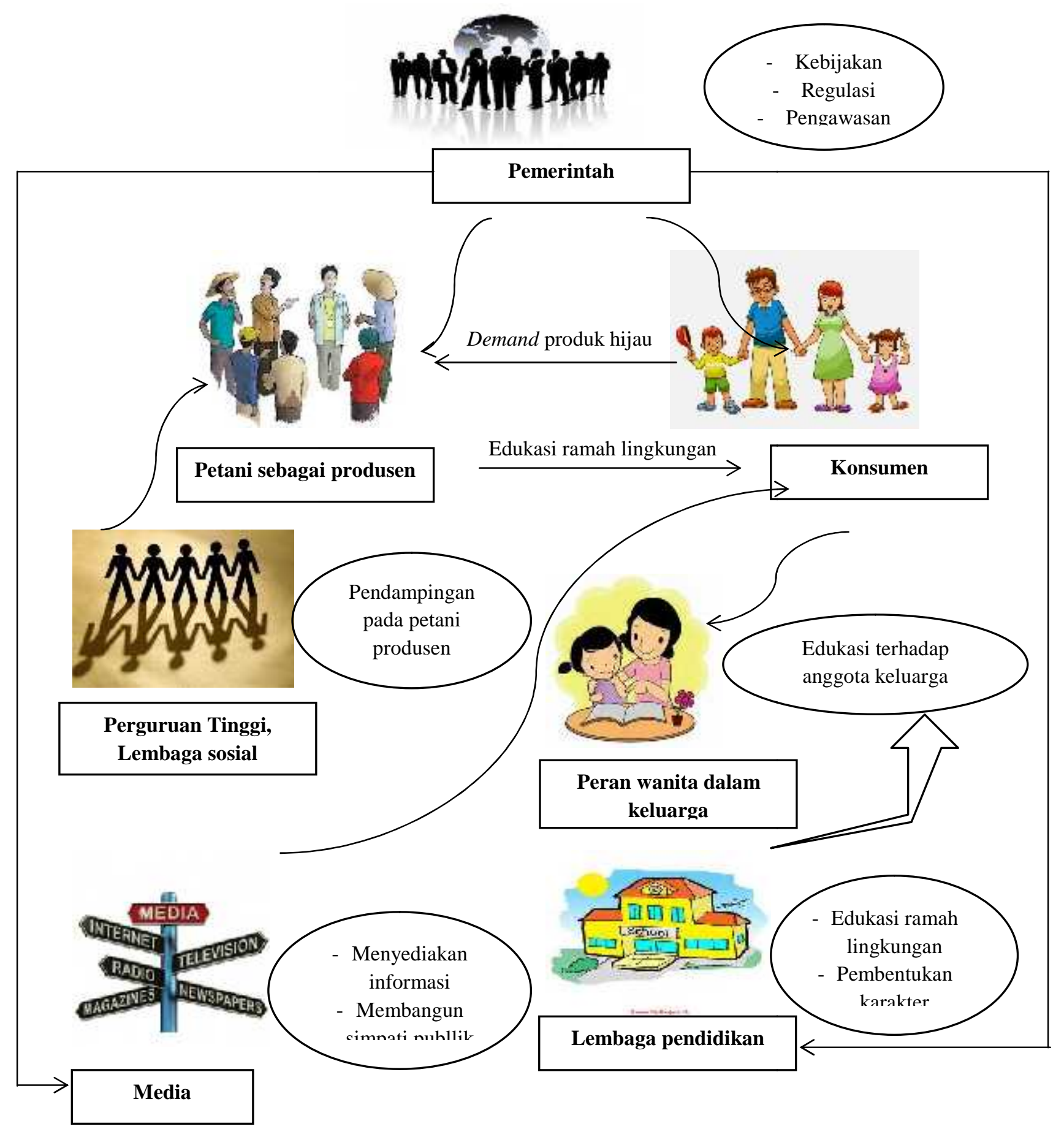

Gambar 1. Peran Berbagai Aktor dalam Membangun Perilaku Ramah Lingkungan

\section{KESIMPULAN DAN SARAN}

\section{Kesimpulan}

1. Secara umum dapat digambarkan karakteristik konsumen yang membeli produk sayur organic di 'Pasar Kecil', sebagai berikut : sebagian besar konsumen adalah wanita yang termasuk golongan usia dewasa, berprofesi sebagai ibu rumah tangga, berlatar pendidikan minimal SMA, dan memiliki pendapatan > Rp. 5.000.000 per bulan. 
2. Dalam memilih produk ramah lingkungan, perilaku konsumen dilatarbelakangi oleh orientasi individu dan orientasi kolektif. Selain keyakinan untuk mengkonsumsi produk ramah lingkungan, pengaruh lingkungan sekitar juga turut mendorong perilaku konsumen.

3. Respon konsumen terhadap edukasi ramah lingkungan yang dilakukan oleh kelompok tani Cipta Mandiri secara umum cukup baik. Konsumen memahami tujuan kegiatan edukasi, konsumen merasa tertarik dengan program edukasi ramah lingkungan dan konsumen berkeinginan untuk melakukan gaya hidup ramah lingkungan.

4. Peran gender memiliki perbedaan yang signifikan dalam variabel orientasi kolektif, respon afektif, respon konatif dan perilaku ramah lingkungan.

5. Diperlukan peran dari berbagai pihak untuk dapat bersama-sama membangun kesadaran berperilaku ramah lingkungan. Pemerintah, produsen, konsumen, lembaga pendidikan dan media massa memiliki peran masing-masing untuk dapat meningkatkan kesadaran berperilaku ramah lingkungan.

\section{Saran}

1. Kelompok tani Cipta Mandiri sebagai produsen sebaiknya lebih gencar mengkampanyekan isu ramah lingkungan dan lebih jelas menginformasikan kegiatan edukasi ramah lingkungan kepada konsumen, agar konsumen menjadi lebih paham akan tujuan kegiatan edukasi yang telah dilakukan.

2. Penelitian ini memiliki keterbatasan dengan kasus konsumen sayuran organic di perkotaan, untuk itu diperlukan penelitian yang lebih luas mengenai pengetahuan, sikap dan perilaku ramah lingkungan beserta faktor-faktor yang mempengaruhinya, sehingga didapatkan model edukasi yang tepat untuk meningkatkan perilaku ramah lingkungan masyarakat dari berbagai macam karateristik demografis.

\section{DAFTAR PUSTAKA}

Bentarjani, Felisitas MP. 2013. Analisis Tipe Perilaku Konsumen Sayuran Organik di Pasar Swalayan Kabupaten Sidoarjo. Skripsi. Surakarta. Universitas Sebelas Maret

Berns, R. M. 1997. Child, Family, School, Community. Socialization and Support. Orlando : Hartcourt Brace College Publishers.

Bronfenbrenner, U. 1981. The Ecology of Human Development : Experiment By Nature and Design. USA : Library of Congress Cataloging in Pubication Data.

Berk Laura E. 1989. Child Development. Massachussets : Allyn and Bacon.

Chan, Ricky Y.K. 1999. Environmental Attitudes and Behavior of Consumers in China: Survey Findings and Implications," Journal of International Consumer Marketing, 11:4, pp. 25-52.

Chan, Ricky Y.K.\& Lorett B. Y. Lau. 2000. Antecedents of Green Purchases: A Survey in China.Journal of Consumer Marketing, Vol. 17 No. 4, pp.338357.

Delita, Nova. 2008. Analisis Perilaku Konsumen Sayuran Segar Pada Supermarket Foodmart di Plaza Ekalokasari Bogor. Skripsi. Bogor. Institut Pertanian Bogor.

Engel, James F, Roger D. Blackwell, Paul W. Miniard.1994. Perilaku Konsumen : Jilid 1. Binarupa Aksara. Jakarta Barat. 
Fakih M. 1997. Analisis Gender dan Transformasi Sosial. Yogyakarta : Pustaka Pelajar.

Fotopoulos, Christos \& Athanasios Krystallis. 2002. Purchasing Motives And Profile Of The Greek Organic Consumer: A Countrywide Survey.British Food Journal, Vol. 104, No. 9, pp.730-765.

Hurlock EB. 1994. Psikologi Perkembangan, Suatu Pendekatan Sepanjang Rentang Kehidupan. Jakarta : Erlangga.

Jiuan, T.S., Jochen Wirtz, Kwon Jung \& Kau Ah Keng. 2001. Singaporeans Attitudes Towards Work, Pecuniary Adherence, Materialism, Feminism, Environmental Consciousness, And Media Credibility.Singapore Management Review, 23, 1, pp. 59-86.

Junaedi, M.F Shellyana. 2008. Pengaruh Gender Sebagai Pemoderasi Pengembangan Model Perilaku Konsumen Hijau di Indonesia. Jurnal Kinerja Volume 12, No 1 Februari 2008.

Konsky, C., J. Blue, M. Eguchi \& S. Kapoor. 2000. Individualist Collectivist Values - American, Indian and Japanese Cross Cultural Study. Intercultural Communication Studies IX-1 Fall 99-00.

Ling-yee, Li. 1997. Effect Of Collectivist Orientation And Ecological Attitude On Actual Environmental Commitment: The Moderating Role Of Consumer Demographics And Product Involvement.Journal of International Consumer Marketing, Vol. 9 No. 4, pp. 31-53.

Nugraheni, P.N.A. 2003. Perbedaan Kecenderungan Gaya Hidup Hedonis Pada Remaja Ditinjau dari Lokasi Tempat Tinggal. Skripsi.. Surakarta : Fakultas Psikologi UMS.

Sethuraman, Raj \& Catherine Cole. 1999. Factors Influencing The Price Premiums That Consumers Pay For National Brands Over Store Brands. The Journal of Product and Brand Management, Vol. 8, Iss. 4, pp. 340.

Setiawan, Iwan. 2012. Agribisnis Kreatif : Pilar Wirausaha Masa Depam, Kekuatan Dunia Baru Menuju Kemakmuran Hijau. Jakarta : Penebar Swadaya

Soekanto, Soerjono. 2002. Sosiologi Suatu Pengantar. Jakarta : Rajawali Press Sumarwan, Ujang. 2003. Perilaku Konsumen : Teori dan Penerapannya dalam Pemasaran.Jakarta : Ghalia Indonesia.

Susilo, Devina. 2014. Analisis Program Corporate Social Marketing, Pengetahuan Konsumen Dan Reputasi Perusahaaan Dalam Menciptakan Green Consumerism (Program Tumbler Starbuck On The Go). Jurnal Manajemen Pemasaran, Vol. 8, No. 1, April 2014.

Yuniarto, Bambang. 2013. Membangun Kesadaran Warga Negara dalam Pelestarian Lingkungan. Yogyakarta : Deepublish 